\title{
Mothering by the Book: Horror and Maternal Ambivalence in The Babadook (2014)
}

\author{
Amanda Konkle 1*
}

Published: September 10, 2019

\begin{abstract}
Attachment parenting strategies underscore the breakdown of the distinction between child and mother, producing an abject horror that is literalised in The Babadook (2014). In this film, a menacing character from a (parenting) book comes to life, and the Babadook threatens the widowed mother, Amelia (Essie Davis) with the darkest part of herself-her desire occasionally to be free from her child's demands. This article reads The Babadook through neoliberal ideologies of intensive parenting and feminist theories about maternal ambivalence and abjection to ultimately argue that the real monster in the film is the pressure to be the perfect mom that comes from the ideologies of intensive mothering. Amelia eventually expels the Babadook from her body in a pool of black vomit, also expelling her abject reaction to motherhood. However, the Babadook is not entirely defeated-instead, Amelia goes to the basement, alone, daily, to feed it. In the basement, she remembers her desire to exist independently of her child, a desire that the film codes as monstrous.
\end{abstract}

Keywords: film, maternal ambivalence, attachment parenting, horror, abject

\section{INTRODUCTION}

A thin, blonde mother, dressed fashionably, stands, breastfeeding her three-year-old son, who is standing on a chair and looking at the camera while latched onto her breast. This image graced not breastfeeding propaganda, but a Time magazine cover in 2012. The cover asked, “Are you Mom Enough?”- - question that implies a fierce dedication to mothering exceeding that of the average mom. The accompanying story discussed attachment parenting 'guru' Dr. Bill Sears, who suggests ways one can improve one's odds of being 'mom enough' (Pickert, 2012). Sears and his wife, Martha, wrote and published the 700-plus-page bestselling attachment parenting 'bible,' The Baby Book, in 1992. Attachment parenting involves a mother's complete devotion to the child, such that the mother eventually anticipates the child's needs and the child never has to cry or act out. Although Sears suggests that working mothers can also be attachment parents, he writes, "As the attachment develops after birth, the mother continues to feel complete only when she is with her baby. When separated from her baby, she feels as if part of herself is missing" (2001: 8). What of those mothers who don't feel incomplete when briefly separated from their children? They might feel like failures, like they aren't 'mom enough.' After all, as Alison Stone points out, the parenting industry is disciplinary; its discourses 'regulat[e]' mothers until their 'confidence and authority drain away' (2012: 18). "When children are measured," Stone notes, "their parents — in practice, mostly their mothersare effectively measured too, as having perhaps hindered their children's development or advanced it less well than they might have done" (2012: 18). The ideology of attachment parenting, also called intensive mothering, is a key player in the 'Mommy Wars' over breastfeeding or bottle-feeding, crying-it-out or waiting-it-out, working or staying at home, and the pressure on mothers to get it 'right.' Mothering, women are told, should be done 'by the book,' but mothering by the book, especially if that book is an attachment parenting tome, can be a horrifying enterprise. Ideologies of intensive parenting underscore the breakdown of the distinction between child and mother, producing an abject horror that traverses national boundaries, ${ }^{1}$ one that is literalised in Australian director Jennifer Kent's 2014 film The Babadook.

1 Attachment parenting is a popular ideology in Kent's Australia, as evidenced by the fact that Sears's book is listed first on the 'Useful Books and Publications' page of the Attachment Parenting Australia website. An article in The Australian, published just four days after the film's Australian release, entitled 'In Defence of Attachment Parenting,' also references the Time cover with which I began this article 
In this film, the (parenting) book comes to life, and its central character the Babadook threatens the widowed mother, Amelia (Essie Davis), with what, because she has internalised the self-surveillance that accompanies the neoliberal ideology of intensive parenting, she considers to be the darkest part of herself-her desire occasionally to be free from her child's demands. Her son, Samuel (Noah Wiseman), reminds Amelia of the car accident that occurred as her husband, Oskar (Ben Winspear), drove her to the hospital to deliver the child, an accident that took her husband's life. The bulk of the film's action occurs in the weeks just before Samuel's seventh birthday. Although Samuel is an older child in this film, viewers see Amelia struggling to be 'mom enough.' Amelia's efforts to establish a definitive boundary between her child and herself indicate an ambivalence toward her child that comes from striving to meet his every need and losing herself in the process.

The film features both other mothers and 'experts' associated with the school, the hospital, and family services who try to tell Amelia how best to raise her child; these experts are representatives of the ideologies of intensive parenting found within popular books throughout western society. These ideologies become a genuine threat first when a mysterious red-bound storybook, titled Mister Babadook, appears in Samuel's bedroom. Samuel soon warns his mother that the Babadook is in their house, and that it is trying to possess and corrupt Amelia, but she only grows more frustrated with him because of these warnings. When the Babadook infiltrates Amelia's body and mind, she expresses negative feelings toward her child, for example, telling him to 'go eat shit,' but she also demonstrates love and concern for her son throughout the film. Amelia eventually expels the Babadook from her body in a pool of black vomit, figuratively expelling her negative feelings toward motherhood and her child. However, the Babadook is not entirely defeated-instead, Amelia goes to the basement, alone, daily, to feed it. In the basement, she remembers her desire to exist independently of her child, a desire that the film codes as monstrous - but only when that desire is ignored or denied. Because she has tamed the Babadook, Amelia is a 'better' mother at the end of the film, as evidenced by her son's successful birthday party-but because the film depicts maternal ambivalence as inescapable, it also critiques the ideologies of intensive motherhood, most commonly expressed in attachment parenting advice. This article reads The Babadook through neoliberal ideologies of intensive parenting and feminist theories about maternal ambivalence and abjection to ultimately argue that the real monster in the film is the pressure to be the perfect mom that comes from the ideologies of intensive mothering.

\section{INTENSIVE MOTHERING: HORROR FROM A WOMAN'S PERSPECTIVE}

To say that The Babadook is a critique of ideologies of intensive mothering is to argue that this horror film is not about an endangered child, but about the terrors that plague the mother. The Babadook is a film written and directed by a woman-perhaps this is why, rather than focus on the child's response to and relationship with the mother (such as in Psycho [1960, dir. Alfred Hitchcock], Carrie [1976, dir. Brian De Palma], or a number of other horror films), The Babadook contemplates the mother's response to and relationship with the child. In this way, The Babadook participates in what Sarah Arnold (2013: 70) has identified as 'a more maternal-centred perspective' in twenty-first century horror films (such as the maternal perspective in The Others [2001, dir. Alejandro Amenábar], for example) (see also Harrington 2016: 202). Noting that The Babadook centers around a maternal perspective is crucial for considering its critique of the horrors of intensive mothering ideologies.

From the film's opening moments, viewers are situated in Amelia's perspective, and this perspective unites two disparate but equally pivotal moments in her life. The initial shots are tightly focused close-ups of Amelia's face as she breathes through contractions in a car, with silence on the soundtrack. A shrieking note accompanies shattered glass smashing into Amelia's face, followed by rumblings and creakings, and a distant groan of "NOOOO!" as we see Amelia tumble back and forth across the frame, totally unmoored from her surroundings. The sense of disorientation only grows as we hear a faint "Mom?" in the background. Amelia turns to look at her husband, who is slumped over the steering wheel, and viewers see a blinding white light indicative of both a further crash and Amelia's waking due to a young boy repeating "Mom! Mommy!" A further disorienting shot shows Amelia falling through the air, arms akimbo, until she lands on the bed and opens her eyes. The boy is now shouting "Mom!," and Amelia sits up. This opening sequence reveals the two defining factors in Amelia's life—her husband's death and her son's demands.

Like many contemporary parents, Amelia's life seems to revolve around her son. While educated stay-at-home moms might choose to invest in mothering the same energies they would have devoted to careers, all mothersworking or not-are subject to the same cultural surveillance that insists that the best mothers mother to the extreme. "Attachment parenting requires sacrifice, dedication, strategizing and a lot of long hours doing thankless tasks. In other words," Belinda Luscombe (2012: n.p.) points out, "it's exactly like climbing the corporate ladder.

(Gambotto-Burke, 2014). This article reads the film through the context of intensive parenting ideologies rather than through a specific national context. 
Except there is no glass ceiling. Or annual bonus." As critics such as Andrea O'Reilly (2010) and Sue Thornham (2013) have pointed out, intensive mothering is at odds with the imperatives of feminism, which advocates for a woman's right to individual subjectivity. According to Thornham, contemporary ideologies of motherhood 'reinscribe the distinction between selfhood and (maternal) female embodiment: as individualised subjects women are urged to mobility and self-definition; as mothers they are re-embodied and returned to place' (2013: 10). Amelia is a working mother, but she is never free from what Lisa Baraitser so insightfully terms the 'interruptions' of caregiving, because she cares for elderly people at work - that is, she experiences 'the transition to motherhood,' which Baraitser associates with 'a certain horror; disintegration' (2009: 63), more acutely because both at home and at work, 'her own self-narrative (...) is punctured at the level of constant interruptions to thinking, reflecting, sleeping, moving and completing tasks' (Baraitser, 2009: 15). The expected loss of selfhood and separateness, the 'constant interruptions' that accompany motherhood, are a horrifying state of affairs, indeed.

Moreover, as Barbara Creed influentially establishes in her essay "Horror and the Monstrous Feminine" (2015), filmic representations of maternal agency are frequently coded as monstrous, and Amelia frequently appears to be a monster, but it is important to consider her monstrosity within the context of these overtaxing ideologies of motherhood. The demands of intensive mothering have made Amelia seem to be a monster because they have destroyed her sense of self. Despite the fact that advocates of intensive parenting tout its virtues, Amelia's problems with mothering correspond with the demands and expectations of attachment parenting. William and Martha Sears insist that:

All parents want their children to grow up to be kind, affectionate, empathetic, well disciplined, and, of course, bright and successful. (2001: ix)

Through pronouncements like these, ideologies of intensive parenting lead to a vigilant self-surveillance against raising a child who is not these things. This common cultural discourse correlates with Amelia's verbalised complaint that Samuel is 'so disobedient he can't go to school anymore' at the beginning of the film. Near the end of the film, she also calls him 'very disobedient' and points out that he 'deliberately disobeyed' her. The film is initially coded to make it seem as if Samuel is a demon child, in keeping with themes from 1960s and 1970s horror films (Rosemary's Baby [1968], The Exorcist [1973], The Omen [1976]): he builds elaborate weapons (shown with a close-up of him sawing a two by four first thing in the morning and the exaggerated diegetic ${ }^{2}$ sound of this undertaking), he fires a heavy ball through the window after his mother yells "please don't!", we see several closeups of his gaping, screaming mouth and his feet kicking the back of the seat in the car, and he looks satisfied after he pushes his cousin Ruby (Chloe Hurn) out of an elevated playhouse. But this is only an initial coding, one designed, perhaps, to get us as viewers to sympathise with Amelia. She is harried, exhausted, frustrated—but for good reason: she is the single parent of a difficult child.

But Amelia is not failing as a mother because she is not trying. Although she doesn't take joy in it, she seems to live by the dictum that 'the mother continues to feel complete only when she is with' her child (Sears, 2001: 8). Samuel will not go to sleep without her, but bed-sharing makes her miserable. This becomes evident when the scene cuts from Amelia reading to Samuel to juxtaposed close-ups of a sleeping Samuel's foot moving across the sheet, his hand kneading the vein in Amelia's neck, and his teeth grinding (all with exaggerated diegetic sound on the soundtrack). The next close-up is of Amelia, prodded and pummelled by Samuel in bed, her eyes open and an annoyed look on her face. And yet, contemporary parents will recognise Amelia's behaviour as aligned with ideologies of attachment parenting, which, as one commentator who parented by the book for a while understands it, suggest that 'it is every child's birthright to sleep nestled between their parents for a couple of years, firmly latched onto a maternal nipple whenever he or she wants' (Eller, 2015: n.p.). Amelia's actions correlate with this advice, but, like the aforementioned critic of attachment parenting, she, too, feels attachment might be great for the child, but not so great for the mother. Amelia blinks slowly and moves Samuel's leg from on top of her, then scoots to the very edge of the bed (so close to the edge that her nose and half her arm hang over the side). The overhead shot shows a gap of a few inches now established between mother and child. The title card follows this scene, suggesting that the Babadook has less to do with Samuel's fears and more to do with Amelia's desires to reclaim an independent selfhood.

Samuel certainly seems calmer and more secure in Amelia's presence; 'from Amelia's perspective, however, their physical intimacy is shown to be deeply intrusive, eroding her sense of herself as a separate subject with her own needs and desires' (Quigley, 2016: 70). Later, when Amelia masturbates, the scene cross-cuts between her relaxing and easing into a moment of release and shots of Samuel (in his separate bedroom) getting out of bed, looking in his closet, and finally bursting into Amelia's room just before she orgasms; he jumps into the bed and shouts about the Babadook being in his room. Although Amelia emphatically states, "This is not going to happen," she does so while pushing Samuel down on the pillow in her bed, suggesting that she feels bed-sharing should

${ }^{2}$ Diegetic sound is sound from within the world of the film. In this case, the sound is diegetic, but its volume is exaggerated.

(C) 2019 by Author/s 
solve Samuel's problem with nightmares. Once again, Samuel throws his arm over her neck and ends up sleeping in Amelia's bed-but this time viewers don't see Amelia remove herself from his hold. Amelia's rage in the film is most commonly associated with her grief over her husband's death (see Quigley, 2016: 61; Jacobsen, 2016), but it is important to consider that the traumatic loss of her husband corresponds with the traumatic loss of her selfhood when she became a mother - a self that, because she is a single parent who also works in caregiving, she is unable to reclaim.

Once the Babadook appears in their lives, Samuel's behaviour seems to escalate to the most extreme limitshe yells at his mother from the back of the car that she will be afraid of the Babadook 'when it creeps into your room at night. You will be when it eats your insides,' and he pushes her down and yells, "Do you want to die?" Surely these kinds of threats are enough to make any mother question her success at child-rearing. As Rozsika Parker puts it, minor forms of violence and aggression against children, such as slapping a child who breaks out of a mother's grasp and runs across the street, occur 'because [the mother] hates the child for behaviour that threatens her with the loss of an internal object called "me-as-a-good-mother", for turning her into a monster, and for obscuring the love and concern that are obviously also there' (1997: 21). Samuel's behaviour indicates to Amelia, and to any onlookers, that she is not 'mom enough,' and, to avoid the unsolicited advice of others, Amelia feels compelled to discipline him.

Amelia is surrounded with those who have advice for her regarding how to raise her (difficult) child: his teacher and principal want him to have a one-on-one monitor because he brought a dart gun to school; her sister tells her that she doesn't visit because she 'can't stand being around [her] son,' and tells Amelia, 'You can't stand being around him yourself;" the doctor tells her that "all children see monsters;" the police laugh at her when she says she is being stalked; and two family services agents pity her and show concern when Samuel says he's 'a bit tired from the drugs mum gave me.' Constantly, Amelia feels compelled to explain herself and her parenting methods. She tells the teacher and principal, whom the low-angle shot underscores as towering authority figures behind the desk, "Samuel doesn't need a full-time monitor. What he needs is some understanding." But they sit in front of a large window, the bright light behind them suggesting they are enlightened 'experts,' while Amelia is small, emotional, and in the dark in the opposing eye-level shot. When Amelia and Samuel retreat into the house, however, beyond these disciplining voices, the dangers increase-perhaps because it is within the house, with only Samuel and her feelings toward him, that Amelia feels the loss of self most acutely.

Amelia can't turn to other mothers for support, either, because in a neoliberal, individualist society, women police the behaviours of other women, and women also make it seem as though motherhood, and the ways women approach it, are freely made choices rather than the result of complex ideologies. Parker discusses 'mothers mirroring mothers,' pointing out that 'mothers both do and do not provide each other with comforting reflections and a place of safety in a society even more critical of mothers than they are of themselves' (1995: 2-3). Amelia encounters the pressures generated by discursive ideologies of mothering when she attends Ruby's birthday party at her sister, Claire's (Hayley McElhinny), house. After Ruby and the other partygoers leave the room, Samuel clings to Amelia's neck as he whines and refuses to let go. The next shot is devastating-Claire's friends (credited as 'Eastern Suburbs Mums': Pippa Wanganeen, Peta Shannon, and Michelle Nightingale), all in sophisticated black clothing that contrasts with Amelia's pink dress, are gathered around the island, and all drop their polite smiles, turn, and stare at this demonstration of Amelia's inept mothering. When she finally pries Samuel away, the other mothers exchange judgmental glances, most of them avoiding eye contact with Amelia.

These other mothers judge Amelia because they cannot empathise with her experience of motherhood-they clearly possess social and cultural capital (as well as financial capital) that she does not. As the mothers complain about their hectic schedules, filled with volunteering with 'disadvantaged women,' some of whom have lost their husbands, and about their husbands' work schedules that leave them 'with the kids 24/7, it feels like,' Amelia can't stop herself from responding: "That's a real tragedy. Not having time to go to the gym anymore, how do you cope? You must have so much to talk about with those poor disadvantaged women." No one responds verbally to this comment, but the reverse-shots show Claire aghast and the other mothers appalled at Amelia's outburst—-they, too, are filmed at a slight low angle with a bright light behind them, echoing the earlier shots with the teacher and principal, while Amelia is again filmed in a seated eye-level close-up, stripping her of authority. The horror of being judged by the same standards as other, wealthier mothers turns on Amelia-she begins to interpret herself as a monster, rather than as a typical mother. This scene highlights the advantages of these 'successful' mothers; for one, they have identities separate from their children, separate from being mothers, and Amelia does not, partly because she hasn't yet been able to admit to herself how much she needs it. Nevertheless, if other mothers are going to police her mothering, Amelia takes this opportunity to point out that she is a single mother who doesn't have assistance with childrearing or a break to go to the gym (suggesting the extent to which intensive mothering is made possible by class privilege).

No wonder Amelia fantasises about time away from her son. When her kind coworker, Robbie (Daniel Henshall), volunteers to cover her shift so she can relax, Amelia goes to the mall. The scene is shot initially through 
the mall's windows, so that reflections and a slight haze erect a barrier between viewers and Amelia, who drifts, alone, through the corridors. We don't hear ambient sound either, but rather a non-diegetic score with rustling and the slow, eerie piano notes associated with horror. When Amelia sits on one end of a couch, alone, eating an ice cream cone, a slight haze and the passing shoppers obstruct our view of her, and when she gets in her car in the parking lot, we see her through the glass of the windshield as she intently watches a couple in a nearby parked car. As Paula Quigley reads it, this scene 'create[s] a sense of her being cut adrift from her surroundings and from "normal life"” (2016: 66). However, the haziness here, and the seemingly bizarre nature of her activity - eating ice cream alone in the mall—seem to connote instead the fantasy of time away from one's child. (Amelia's behaviour here resonates with the behaviour of many contemporary mothers, who admit, on social media groups, to the joys of drinking coffee alone in a parking lot.) Perhaps critics have missed reading this scene as such because many viewers aren't used to thinking of mothers as having desires independent of their children's well-being? If we consider Amelia's perspective as a mother's perspective, we might read these scenes not as indicating that Amelia is adrift and isolated, but rather as indicating her fantasies — fantasies that she keeps safe by containing them behind glass, and fantasies that are horrifying according to ideologies of intensive motherhood, because they suggest that a mother has interests and desires that do not involve her child.

Exploring horror from the woman's, and in particular, the mother's, perspective allows the film to consider what the mother's fantasies and fears might be. And many of those fantasies and fears are caused not just by the contradictory and intense experience of mothering, but also by the ideologies surrounding attachment parenting and intensive mothering. For example, a crucial aspect of forming an independent identity (a project that, under neoliberalism, every individual should complete upon adulthood) entails a certain degree of selfishness; however, 'attachment makes selfishness impossible' (Gambotto-Burke, 2014). To consider what attachment parenting feels like from the mother's perspective, we have to think about the mother's 'unconscious fantasy' (Parker, 1995: 64) of herself as a perfect mother, a fantasy inspired at least in part by cultural ideologies surrounding motherhood. According to Patrice DiQuinzio (1999), 'essential motherhood,' or the notion that women exist to be mothers and are 'naturally' suited to succeed at and enjoy mothering, makes the mother's fantasies of what mothering will be like all the more damaging; 'essential motherhood requires mothering of women, but it represents motherhood in a way that denies mothers' and women's individualist subjectivity' (xiii). When women fantasise about being 'mom enough,' they are bound to fail, and the guilt of such a failure might be enough to make them monstrous.

\section{MONSTROUS MOTHER OR MATERNAL AMBIVALENCE?}

And, in fact, a critical tendency has been to divide mothers in films into 'good mothers' and 'bad mothers,' with both bound to fail their children in one way or another. In the terms established by classical analyses of the 'Bad Mother,' such as those by Carol Clover (1992) and Linda Williams (2000), good mothers are de-eroticised, and bad mothers are 'phallic,' or smothering and intent on dominating their children. Arnold rethinks this framework for the twenty-first century, however, arguing,

The Bad Mother is not only a product of the patriarchal imaginary, or a representative of the nightmare unconscious, but also a transgressive figure who resists conformity and assimilation. Her very transgressions often indicate the slipperiness of patriarchy. The Bad Mother can point to dissatisfaction and disillusionment with the psychosocial structures of the family. (69)

Erin Harrington surmises that "where a "good" mother makes extraordinary sacrifices, a "bad" mother's sacrifice result[s] in a loss of her sense of self (2016: 206). In other words, a 'bad' mother might reflect not her personal failings, but the failure of cultural discourses around mothering that make her read her own efforts as failures. As Harrington points out:

Horror films are a space in which historically specific hopes and anxieties about the nature of motherhood and maternal affect are variously articulated, enforced and challenged, instead of bluntly represented as 'good' or 'bad'. (2016: 183)

Rather than think of Amelia as a monster, then, we should question the monstrous aspects of motherhood upon which the film is commenting.

It is undeniable that Amelia and the monster are aligned. For example, when Samuel has a bad dream, she goes into his room and checks for monsters - but when she does so, the shots are from under the bed and within the closet. That is, we now see Amelia and Samuel from a monster's perspective, a momentary point of view shift that, because viewers have already been aligned with Amelia's perspective, suggests a unity between Amelia's and the monster's perspectives. When we consider maternal ambivalence, or, as D. W. Winnicott insisted as early as 1949, the psychological commonplace that 'the mother (...) hates her infant from the word go' (1994: 355), Amelia 
comes to seem even more monstrous. But ambivalence is common: Parker (1995), a psychoanalytic psychotherapist, defines maternal ambivalence as 'the experience shared variously by all mothers in which loving and hating feelings for their children exist side by side' (1). 'All mothers' experience, at times, feelings of hatred for their children, but as Parker points out, 'our culture (...) virtually prohibit[s] the kind of full discussion and exploration' that would normalise these feelings and make them bearable (1). Incidentally, up until the very late twentieth century, maternal ambivalence was also discussed primarily from the child's perspective, and in terms of its impact on the child, rather than from the mother's perspective and in terms of its impact on the mother (see Parker, 1995: 12). The Babadook challenges this historical framing of maternal ambivalence. The monster in the film is not the mother, but the combined effects of ideologies of intensive mothering and the interference of 'experts,' both of which tell Amelia she is a 'bad' mother, and a culture that makes it unacceptable for a mother to express her (very typical) frustrations with mothering.

The film expresses not a mother's desire to annihilate the source of her frustration, but rather her ambivalent feelings of alternating love and hate for her child. For example, when Samuel caresses Amelia's face in an early scene, she closes her eyes and seems to enjoy the affection, but when he hugs her as tightly as he can a moment later, she pushes him away and growls, "Don't do that!" This early scene indicates that Samuel is aware of how his mother's ambivalence makes it impossible for her to develop a connected relationship with him and to feel good about her accomplishments as a mother. But she does care about and effectively mother her son-she chastises both the school principal and her hallucinated husband for referring to Samuel as 'the boy,' and vows to find an appropriate school for him. The reason she can't express her frustrations alongside her victories is because motherhood has been essentialised as something women are inherently good at and inherently relish, to the extent that mothers are criticised for expressing (outside of what Parker [1995:66] has noted is the socially acceptable form of satire) the frustrations that accompany motherhood. The monster in the film is the institutionalised pressure to be 'mom enough,' to never want to be away from one's child.

Significantly, the film acknowledges that these feelings of maternal ambivalence are nearly universal. For example, Samuel repeats over and over that he is hungry after Amelia has not slept all night, calling to mind the incessant demands of children everywhere. Amelia's response, at least initially, is also a familiar maternal complaint, albeit phrased in harsher terms: she growls, "Why do you have to keep talk, talk, talking? Don't you ever stop?" and, "If you're that hungry, why don't you go and eat shit?" But Amelia doesn't relish that Samuel runs away from her after she says this_-instead, she rises from bed and speaks softly to Samuel, apologising and offering to cook him something. In case that scene seems too extreme to express a universal maternal ambivalence, when Amelia takes Samuel to a diner for ice cream because of her remorse about this comment, they sit in a booth adjacent to a mother (Alicia Zorkovic) who is arguing with and disciplining five unruly children (India Zorkovic, Isla Zorkovic, Charlie Crabtree, Ethan Grabis, Sophie Allan). Although Samuel sits quietly sipping his milkshake, Amelia and the other frustrated mother are positioned to mirror each other on the far left and right sides of the shot-and both frown as they lean in the direction of their children. Surely this scene resonates with anyone who has taken even one child to a restaurant, and reminds parents of some of the freedom and peace they lose when they gain children.

But if we look beyond the ideology of intensive mothering, we find that many psychologists note that maternal ambivalence is both normal and healthy — as long as it is acknowledged rather than denied. As Parker explains, 'it is the mother's achievement of ambivalence - the awareness of her coexisting love and hate for the baby - that can promote a sense of concern and responsibility towards, and differentiation of self from the baby. Accordingly, both idealisation and denigration of her baby diminish' (1997: 16). Parker argues that maternal ambivalence can lead to creative solutions: consider, for example, the image in the lullaby 'Rock-a-by-baby' of the cradle falling from a high tree (1995: 63). When faced with a baby that continues to cry, mothers can both sing their frustrations and soothe the baby simultaneously — that is, they can express their ambivalence creatively.

Such a theory provides support for the notion that Amelia, as a woman who used to write 'magazine articles' and 'kids' stuff,' might be responsible for not only the violent actions that the Babadook causes but also the storybook itself. After Oskar's death and Samuel's birth, Amelia no longer writes children's stories. As Stone argues about writing and maternal subjectivity, "The subject is one who actively gives meaning to his or her experience (in speech, writing, or other modes), and who can do so only because at some level he or she identifies as the single agent performing this activity" (2012: 15). Amelia's individual subjectivity is subsumed in motherhood, and that sudden and total abandonment of her independent self, and her writing, ultimately results in the impulse to express her desire to be rid of her son, initially only in fiction. The storybook of Mister Babadook is a creative expression of her resentment of Samuel. The DVD version's home screen underscores this solution when it opens with Amelia reading, "Whether it's in a word or it's in a book, you can't get rid of the Babadook," the first line of the story of Mister Babadook, suggesting that her word and the book might be the same. It is telling that the last several pages of the storybook are blank, waiting for the details of Amelia's and Samuel's story to emerge. If the story of Mister Babadook is Amelia's use of the horror genre to explore her feelings toward her son, expressing those feelings, in a 


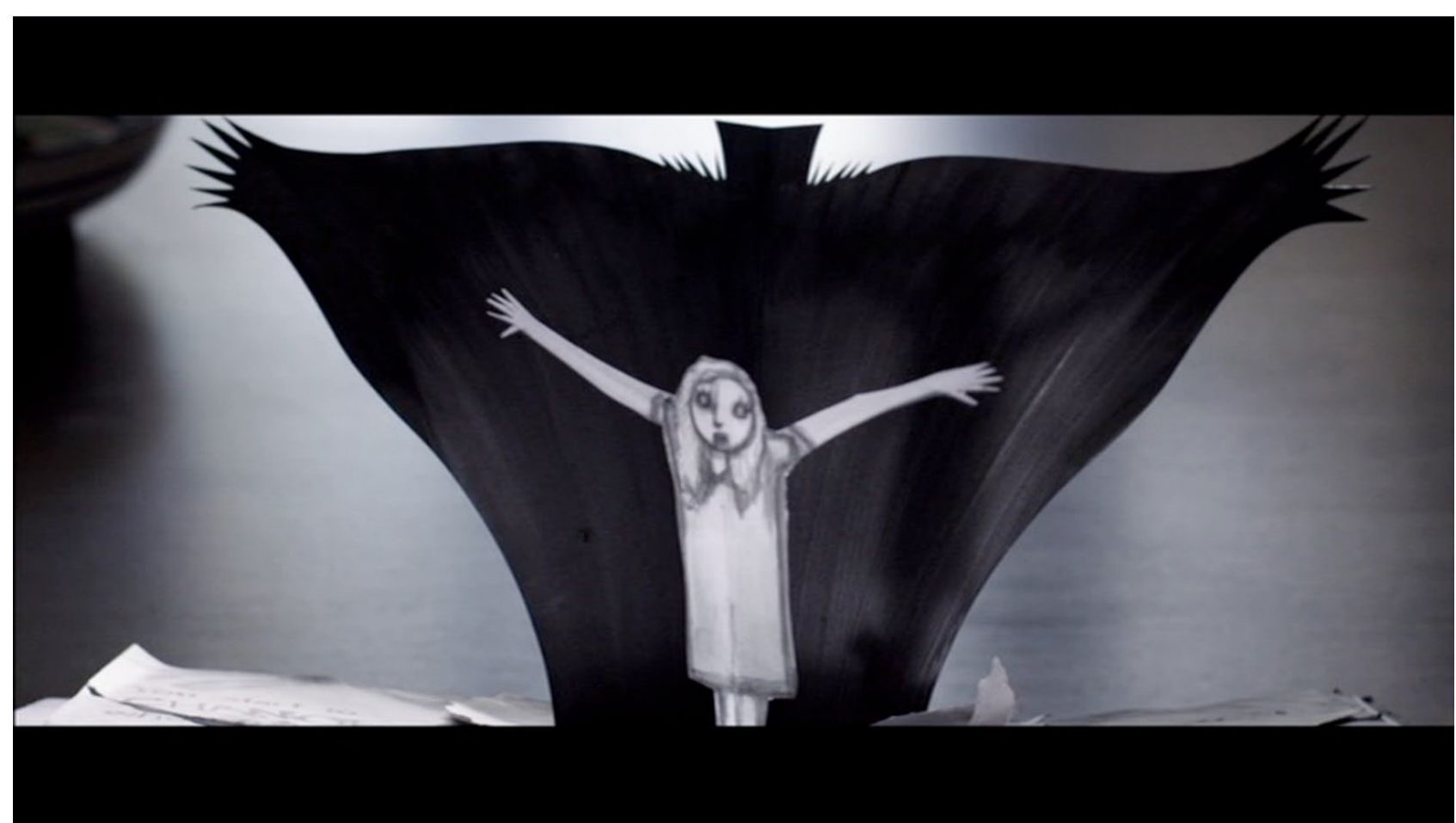

Figure 1. The mother and the Babadook are intertwined. Frame from The Babadook (Screen Australia, Causeway Films)

culture in which mothers are told to sacrifice individuality and that their children are the only thing that will make them feel complete, truly horrifies her. As Quigley notes,

As Amelia's mask of maternal self-sacrifice begins to slip, the conventions of the horror genre provide a vocabulary capable of articulating the 'real' feelings beneath Amelia's façade. (2016: 70)

The storybook, whose title Babadook seems to echo a child's attempt at saying 'baby book,' becomes another parenting book whose shadow and influence the harried mother cannot escape, and therefore, like The Baby Book and other attachment parenting manuals, it takes on a life of its own and gives Amelia more grief than support.

What does the storybook of Mister Babadook tell Amelia - and, according to this reading, what does Amelia tell herself-about who she is as a mother? "The more you deny, the stronger I get," the book reads. "You start to change when I get in, the Babadook growing right under your skin." One crucial pop-up in the book features a woman, in a nightgown similar to the one Amelia wears throughout the film, with her arms spread above her head. A large shadow with the top hat and pointy fingers of the Babadook extends behind her, suggesting that the woman and the Babadook are intertwined (Figure 1). The next pages feature elaborate pop-ups of a woman strangling a child and then cutting her own throat. The storybook, I argue, expresses Amelia's ambivalent feelings toward her son; the Babadook is a projected embodiment of her rage and frustration with the demands of parenting, not to mention the added pressure to be the 'perfect' parent despite the difficult circumstances of this family.

First Amelia begins to see the Babadook everywhere, and then she begins to change as a mother, no longer concealing her frustrations with Samuel, but now giving them voice. For example, when she tries to convince the police that someone is stalking her and her child, she quickly stops when she sees a jacket with the Babadook's long, thin fingers hanging on the wall. She later hallucinates roaches crawling out of the wall behind the refrigerator and begins frantically cleaning the house. These roaches seem to express the disgusting, not-me feelings Amelia has about being a parent_-feelings that, as the storybook says, will make you 'wish you were dead.' And while the house in which Amelia and Samuel live is dark, stuffy, and entrapping, it's important to note that the Babadook follows them when they leave the house. For example, Amelia sees it creeping on the roof of the car, after she sees roaches crawling on her dress, and crashes into another driver. These are additional indications that the Babadook is intertwined with Amelia.

As the film continues, Amelia becomes a danger to her son, but not until the final battle with the Babadook is she wholly consumed by rage and aggression. Before that, she might lash out at Samuel, but she also lovingly apologises. Even when she's almost wholly consumed by the Babadook, and Samuel tries to wake her, she refers to him as 'sweetheart.' Similarly, when she hallucinates Samuel lying on the couch with mouth gaping and blood running down his face and chest, she is horrified - and becomes even more horrified when she wakes from this hallucination to find that she is standing over a terrified Samuel with a knife in her hand. Although Amelia becomes, 
as Harrington notes, 'the monstrous antagonist of the story,' it is also important to point out, as Harrington does, that Amelia endangers Samuel because 'she cannot live up to the impossible ideals of motherhood, and she cannot do what is, supposedly, a natural and essential part of a woman's experience' (2016: 180). Thus, while Amelia is aligned with the monster, she is also attacked by it, both articulating and challenging discursive ideologies of motherhood.

\section{THE IMPORTANCE OF BOUNDARIES}

Amelia certainly looks monstrous throughout the last half of the film—she breaks the family dog's neck, pulls out her own bloody tooth, and climbs the door jamb of Samuel's room in a supernatural feat of strength. But, as David Greven (2011: 13) points out, as is common in films that blend horror and melodrama, Samuel is not repulsed by the mother, but drawn to her. She looks horrifying not because she represents what disgusts Samuelthe abject mother-but because there is something within her that is not-her-she has been impregnated with the abject Babadook and has to expel it to reestablish her bodily integrity. Julia Kristeva's theory of the abject in Powers of Horror (1982) has been highly influential in film studies, especially in terms of thinking of the 'monstrousfeminine,' in Barbara Creed's (2015) terms. In Kristeva's theory, abjection contributes to identity formation-the child learns to differentiate him or herself from the mother by seeing the mother's body as abject, as the opposite of the child's independence and liveliness. As Creed summarises it:

One of the key figures of abjection is the mother who becomes an abject at that moment when the child rejects her for the father who represents the symbolic order. (2015: 38)

But such a theory works only when the horror aligns us with the child's perspective, and The Babadook is about what horrifies mothers.

Thus it is necessary to think a bit more about how Kristeva defines the abject. Kristeva points out that the abject is caused by 'what disturbs identity, system, order. What does not respect borders, positions, rules' (1982: 4). The child learns to separate itself from the mother by seeing the mother as abject. In a crucial discussion of the corpse, Kristeva writes:

Abject. It is something rejected from which one does not part, from which one does not protect oneself as from an object. Imaginary uncanniness and real threat, it beckons to us and ends up engulfing us. (1982: 4)

That is, the abject is both horrifying and attractive. If the child does not definitively separate him/herself from the mother, he risks the danger of not forming a unique, separate identity—and, in turn, if the mother does not maintain an identity separate from her child, she might also be in danger. As Arnold explains, Kristeva discusses the maternal body as 'a site of many of those things which are abjected (breast milk, menstrual blood), and she points back to a time of non-differentiation between the child and mother' (2013: 14). But, Arnold continues:

The abject is not something, therefore, that is inherently evil or 'bad', since to be so is to be distinct from the self. The abject is that which, like Freud's uncanny, points back to origins, to a time before self: birth, mother-child symbiosis. (2013: 14-15)

The abject points to the breakdown of boundaries between child and mother-and recalling 'mother-child symbiosis' is as likely to 'disturb identity' for the mother as it is for the child.

Motherhood is, after all, an experience which blurs the boundaries between the self and the other; those mothers who experience pregnancy and bear their own children literally experience a prolonged period when the child is a part of themselves. For Kristeva, abjection is a loss of one's personal identity, and an identity that is constituted by some other: "I experience abjection only if an Other has settled in place and stead of what will be 'me"' (1982: 10). Thus, while Kristeva explains that subjects always establish their identities by differentiating themselves from the mother's abject (disgusting, terrifying) body, she does not discuss how a mother might form an identity separate from her child. Surely the mother is not bound to only see herself also as monstrous, terrifying, and abject. José Esteban Muñoz's concept of disidentification provides a way of rethinking representations of maternal abjection. Muñoz writes that

disidentification scrambles and reconstructs the encoded message of a cultural text in a fashion that both exposes the encoded message's universalizing and exclusionary machinations and recircuits its workings to account for, include, and empower minority identities and identifications. (1999: 31) 
Although Amelia sees herself as abject until her final battle with the Babadook, perhaps the film can help mothers recognize the limiting dominant ideologies of motherhood and envision the many unique identities that mothers possess.

Thus, the horror in The Babadook becomes tied to the eroded boundaries between mother and child (boundaries that were eroded because of the pressures of the ideologies of intensive mothering). Creed points out that 'that which crosses or threatens to cross the "border" is abject' (2015: 42). One's child certainly crosses a border when it gestates inside the mother, but children also continually violate the border between mother and child when they insist on being in the mother's space, following the mother to the bathroom, calling for the mother, and touching the mother. Might the mother instead see the breaking down of boundaries between self and Other that occurs when one forms attachment bonds with one's child as threatening to her identity in the same way that the child sees the fusion between mother and self as threatening to his/her entrance into the Symbolic Order? As noted previously, the constant interruptions of caregiving make writing difficult, and thus threaten the mother's sense of her individuality, her sense of herself as part of the Symbolic Order as well. But Baraitser contends 'that motherhood lends itself to anecdote rather than the grand narrative of "mother-writing" due to the constant attack on narrative that the child performs' (15). Within The Babadook, Samuel embodies all those things that remind Amelia of the fragility of her body and independence; her son threatens the borders she constructs around herself, he threatens her with non-differentiation. In other words, encountering the abject for the mother would produce a desire for the eroded boundaries separating mother and child to be restored.

Amelia's desire for boundaries is clear throughout the film. When Amelia gives Samuel sedatives to help him sleep (in his own bed, alone), she descends into her bed from above in a shot that echoes the shot of her awakening from the film's opening nightmare-but this time her face is contented, and her arms lie still at her sides. She is happy to know that she has this reprieve from her son and his demands-as Baraitser theorises about maternal subjectivity, mothers might find themselves reduced to tears by a sleeping child because in sleep, the child's capacity for separateness is simply shown up in relief, and for a few moments it makes (the mother) weep (...) because of a sudden realisation that the child already knows how to separate' (2009: 109). Amelia is desperate for these moments of separateness. Later, Samuel, out of desperation, tries to call Mrs. Roach (Barbara West) and Auntie Claire, but Amelia takes the batteries out of the phone handset, cuts the phone lines, and turns Mrs. Roach away, insisting that they're 'ok' - and thereby establishes boundaries around this family unit. When Samuel tells her he's trying to protect them from the Babadook and shouts, "I just didn't want you to let it in," she responds, "Nothing is coming in here tonight. Nothing!" While this scene hints that she will harm Samuel, it is also crucial to understanding how much of Amelia's possession stems from the need to establish boundaries between the me and the not-me. When the Babadook's possession of her allows her to express her extreme frustration, she endangers Samuel, because she has not been able to acknowledge her ambivalence. But, possessed by the Babadook, she freely admits: "You don't know how many times I wished it was you, not him, that died. ... Sometimes I just want to smash your head against a brick wall until your fucking brains pop out." Samuel responds, "You're not my mother!" She asks him to repeat himself; when he does, she screams, "I am your mother!" The Babadook allows Amelia to express her rage and frustration with mothering-but it also forces her to claim her maternal identity.

Even when she is fully possessed by the Babadook, Amelia alternates between love and hate. She apologises to Samuel for not being good since Oskar's death-but it turns out that she is using claims that "I want to make it up to you, Sam" to be able to get close enough to him to strangle him so he can 'meet [his] dad.' She has nearly superhuman strength at this point, but Samuel jams a kitchen knife into her leg, and when she follows him into the basement, clubs her so that she passes out on the floor, where he can tie her up to protect himself. Samuel refuses to leave her, saying, "We said we'd protect each other. I know you don't love me. The Babadook won't let you. But I love you, mum. And I always will." Amelia becomes tearful at this confession, perhaps because he here acknowledges that he is distinct from her. Then Samuel encourages his mother to 'get it out.' In this way, the film can be cathartic for any mothers in the audience who also feel frustration about mothering and a need to 'get it out.' Amelia frees her hand and begins strangling him, moaning and weeping as she does so-she is finally expressing her simultaneous hate and love for her child. Her grimace and grip soften when Samuel caresses her face, just as he did at the beginning of the film. She shakes violently, but finally vomits an inky black puddle and collapses on the floor.

While Amelia thinks this is the end of it, Samuel states, "You can't get rid of the Babadook" as the Babadook hurls Samuel's body up the stairs. And indeed, if maternal ambivalence is normal and healthy, it is important that Amelia can't get rid of it. But once she expels the Babadook, Amelia is also freer to express her love for and protectiveness of her son. And that love for and protectiveness of her son, she realises, can only be fully expressed once she establishes some boundaries. To finally subdue the Babadook, she shouts, "This is my house. You are trespassing in my house. If you touch my son again I'll fucking kill you!' The Babadook tries to pull Samuel out 
of Amelia's grasp, but her hold on him is too strong, proving that establishing boundaries strengthens her ability to protect her son.

The Babadook exposes and critiques the ideologies associated with contemporary motherhood, especially those that would insist on the intensive mothering correlated with attachment parenting. The film takes a different approach from that of most horror films about mothers, which, as Harrington argues, 'suggest that the precarious balance between the needs of the self and the demands of motherhood can only ever end in destruction of the mother and/or her child' (2016: 184). Amelia and Samuel approach destruction, but in the end, neither of them is destroyed. Instead, after Amelia locks the Babadook in the basement, she scoops Samuel into her arms and kisses him for the first time in the film. This is a film, as Hazel Cills puts it, 'about a mother against a valid and vulnerable part of herself (2014, my emphasis). That 'valid and vulnerable part of herself is her ambivalence, and, as Harrington notes, the 'monstrous' 'notion that a woman can and should be judged using a set of impossible criteria against which she will always be found wanting' (2016: 214). That the film validates Amelia's ambivalence is crucial to understanding how it critiques and challenges contemporary ideologies of attachment parenting and essential and intensive mothering.

But does the film ultimately transform motherhood? After all, at the end of the film, Amelia seems to have not one, but two, difficult children to nurture-one of them the roaring, rage-filled Babadook who now lives in her basement. Whether we see the film as challenging contemporary ideologies of intensive mothering depends on what we interpret the Babadook to represent. If it represents Amelia's grief at the loss of her husband (which is how many reviews of the film interpret it), then the figure of the Babadook might seem to be Amelia's longing for a literal embodiment of the patriarchal 'law of the Father' to relieve her of the burdens of being both nurturer and authority figure - in other words, it might suggest that she would be better off if she was not a single mother, but rather one more fully embroiled in the patriarchy.

If, however, the Babadook is an embodiment of Amelia's own ambivalence toward motherhood, we might interpret her nurturing this ambivalence as a positive step toward challenging the ideologies associated with contemporary motherhood. The basement is off limits throughout the film; it is where Amelia keeps Oskar's things, which she avoids. But at the end of the film, the basement is off limits only to Samuel. Amelia visits the basement almost ritually, without Samuel, and quiets the Babadook's rage in that space separate from her child. In fact, when the Babadook tries to bend her under the weight of its rage, she pushes against it, repeating three times, in a kind of ritual chant, "It's alright." Parker, drawing on Jessica Benjamin, indicates that 'the recognition by a mother that she has her own needs and priorities is (...) crucial for a child's development' (1997: 20). For Amelia, this space separate from her child, where she confronts and quiets her rage, is also a space that makes her a better mother. After Amelia returns from feeding and calming the Babadook, she tenderly strokes the bruise on Samuel's neck, a bruise that he got when she, filled with the Babadook's rage, tried to strangle him. Samuel comments that "it's getting better, mum," referring both to the bruise and their relationship.

As O'Reilly points out, 'to say that the boredom, exhaustion, ambivalence, guilt, loneliness, anxiety, and selfdoubt mothers feel is normal and common-indeed more real than the contented, calm, and composed mother found in magazines - is therapeutic, indeed liberating' (2010: 209). The Babadook is a film that opens itself to various interpretations. It expresses feelings of rage, grief, the desire for independence, and love, and ultimately accepts maternal ambivalence. Crucial to this reading of the film's critique of parenting 'by the book' is the fact that the film gives Amelia one final chance to confront the authorities: the family services agents return on the day of Samuel's birthday party. This time, though, the camera is at a slightly higher level when focused on Amelia and Samuel, and both Amelia and Samuel and the agents are in normal ambient light. That is, Amelia has demonstrated that she as a mother does have some authority over the raising of her child, and she no longer has to mother "by the book.' Like Cynthia Eller (2015), a mother who writes about succumbing to the pressures of attachment parenting, who 'renamed The Baby Book "How to Be a Perfect Mother and Why You'll Never Be One,"” and now keeps the book in the garage for occasional reference, Amelia keeps the Babadook locked away in the basement.

The film's final sequence is crucial to understanding what has been accomplished. Only after Amelia has quieted the Babadook-her feelings of frustration and rage- by telling Samuel to get out of the house and stay out until she comes up from the basement, can she embrace spending time with him doing magic tricks, preparing for his birthday party, and cradling him on her lap. The film's final shot is a close-up of Amelia's face, and the film doesn't go to extremes in creating this happy ending-Amelia is smiling, but only slightly, as she holds Samuel's head against her chest. This fact, combined with the Babadook who remains in the basement, indicates that the film is realistic about maternal ambivalence as a lifelong condition. If neoliberal ideologies of self-surveillance result in the ideologies of parenting that insist that mothers can have it all and do everything perfectly, then perhaps a cultural recognition and representation of the difficulties and frustrations of mothering, of maternal ambivalence, will help other mothers resist the demands to mother by the book in the future. 


\section{REFERENCES}

Arnold, S. (2013). Maternal Horror Film: Melodrama and Motherhood. New York: Palgrave Macmillan. https://doi.org/10.1057/9781137014122

Baraitser, L. (2009). Maternal Encounters. The Ethics of Interruption. London: Routledge. https://doi.org/10.4324/9780203030127

Cills, H. (2014). Mother dearest: how 'The Babadook' inverts the horror-movie mom. Grantland. December 18. Available at: http://grantland.com/hollywood-prospectus/mother-dearest-how-the-babadook-inverts-thehorror-movie-mom/ (Accessed 10 October 2018).

Clover, C. (1992). Men, Women, and Chainsaws: Gender in the Modern Horror Film. Princeton, NJ: Princeton University Press.

Creed, B. (2015). Horror and the monstrous feminine: an imaginary abjection, in B.K. Grant (ed), The Dread of Difference: Gender and the Horror Film (pp. 37-67). Austin: University of Texas Press.

DiQuinzio, P. (1999). The Impossibility of Motherhood: Feminism, Individualism, and the Problem of Mothering. New York: Routledge.

Eller, C. (2015). Why I hate Dr. Sears. Brain, Child Magazine. June 4. Available at: https://brainchildmag.com/2015/06/why-i-hate-dr-sears/ (Accessed 18 October 2018).

Gambotto-Burke, A. (2014). In defence of attachment parenting. The Australian. May 26. Available at: https://www.theaustralian.com.au/life/in-defence-of-attachment-parenting/news-story/42362ab337ee9f55b 44009bd7e794bd6. (Accessed 8 October 2018).

Greven, D. (2011). Representations of Femininity in American Genre Cinema: The Woman's Film, Film Noir, and Modern Horror. New York: Palgrave Macmillan. https://doi.org/10.1057/9780230118836

Harrington, E. (2016). Women, Monstrosity, and Horror Film: Gynaehorror. London: Routledge. https://doi.org/10.4324/9781315546568

Jackson, K. (2016). Gender and the Nuclear Family in Twenty-First-Century Horror. New York: Palgrave Macmillan. https://doi.org/10.1057/9781137532756

Jacobsen, P. (2016). Eye on fiction: The Babadook and maternal depression. The Psychologist ... November. Available at: $\quad$ https://thepsychologist.bps.org.uk/volume-29/november-2016/babadook-and-maternal-depression (Accessed 18 October 2018).

Kristeva, J. (1982). Powers of Horror: An Essay on Abjection. L.S. Roudiez (trans). New York: Columbia University Press.

Luscombe, B. (2012). How feminism begat intensive mothering. Time. May 10. Available at: http://ideas.time.com/2012/05/10/how-feminism-begat-intensive-mothering/ (Accessed 8 October 2018).

Muñoz, J. (1999). Disidentifications: Queers of Color and the Performance of Politics. Minneapolis: University of Minnesota Press.

O'Reilly, A. (2010). The motherhood memoir and the 'new momism': biting the hand that feeds you, in E. Podnieks and A. O'Reilly (eds), Textual Mothers / Maternal Texts: Motherhood in Contemporary Women's Literatures (pp. 203213). Waterloo, Ontario: Wilfrid Laurier University Press.

Parker, R. (1995). Torn in Two: The Experience of Maternal Ambivalence. London: Virago.

Parker, R. (1997). The production and purposes of maternal ambivalence, in W. Hollway and B. Featherstone (eds), Mothering and Ambivalence (pp. 15-22). London: Routledge.

Pickert, K. (2012). The man who remade motherhood. Time. May 10. Available at: http://time.com/606/the-manwho-remade-motherhood/ (Accessed 8 October 2018).

Quigley, P. (2016). When good mothers go bad: genre and gender in The Babadook. Irish Journal of Gotbic and Horror Studies, 15, 57-75.

Sears, W. and Sears, M. (2001). The Attachment Parenting Book. A Commonsense Guide to Understanding and Nurturing your Baby. Boston: Little, Brown and Company.

Stone, A. (2012). Feminism, Psychoanalysis, and Maternal Subjectivity. London: Routledge.

The Babadook. (2014). Written and directed by Jennifer Kent. Screen Australia, Causeway Films, and The South Australian Film Corporation.

Thornham, S. (2013). 'A hatred so intense...': We Need to Talk about Kevin, postfeminism and women's cinema. SEQUENCE: Serial Studies in Media, Film and Music, 2(1), 1-36.

Useful Books and Websites. Attachment Parenting Australia. (n.d.). Available at: http://www.attachmentparentingaustralia.com/books.htm (Accessed 8 October 2018).

Williams, L. (2000). 'Something else besides a mother': Stella Dallas and the maternal melodrama, in E.A. Kaplan (ed), Feminism \& Film (pp. 479-504). New York: Oxford University Press.

Winnicott, D. W. (1994). Hate in the counter-transference. Journal of Psychotherapy Practice and Research, 3(4), 350-356. 
Citation: Konkle, A. (2019). Mothering by the Book: Horror and Maternal Ambivalence in The Babadook (2014). Feminist Encounters: A Journal of Critical Studies in Culture and Politics, 3(1-2), 04. https://doi.org/10.20897/femenc/5910

Copyright $(0) 2019$ by Author/s and Licensed by Lectito BV, Netherlands. This is an open access article distributed under the Creative Commons Attribution License which permits unrestricted use, distribution, and reproduction in any medium, provided the original work is properly cited. 